\title{
Dose-dependence of protection from systemic reactions to venom immunotherapy by omalizumab
}

\author{
Elisa Boni ${ }^{1^{*}}$ (D), Cristoforo Incorvaia ${ }^{2}$ and Marina Mauro ${ }^{1}$
}

\begin{abstract}
Background: Systemic reactions (SR) to venom immunotherapy (VIT) are rare but may occur, with a rate significantly higher for honeybee than for vespid VIT. In patients with repeated SRs to VIT it is difficult to reach the maintenance dose of venom and pre-treatment with omalizumab is indicated, as shown by some studies reporting its preventative capacity, when antihistamines and corticosteroids are ineffective.

Case presentation: We present the case of a 47 years old woman allergic to bee venom who experienced two severe SRs after bee stings and several SRs to VIT with bee venom. Pre-treatment with antihistamines and corticosteroids as well as omalizumab at doses up to $300 \mathrm{mg}$ was unsuccessful, while an omalizumab dose of $450 \mathrm{mg}$ finally achieved in our patient the protection from SRs to VIT with 200 mcg of bee venom.

Conclusions: The search of the dose of omalizumab able to protect a patient with repeated SRs to VIT may be demanding, but this search is warranted by the need to provide to this kind of patient, by an adequate VIT, the protection from potentially life-threatening reactions.
\end{abstract}

Keywords: Venom immunotherapy, Honeybee, Systemic reactions, Omalizumab

\section{Background}

Venom immunotherapy (VIT) is generally safe and, differently from injective immunotherapy with inhalant allergens, no fatal reaction to treatment has been reported [1]. Still, systemic reactions (SR) may occur, with a rate significantly higher for honeybee than for vespid VIT. In fact, a systematic review defined a rate of SRs of $25.1 \%$ for honeybee VIT and $5.8 \%$ for vespid VIT [2]. In patients with repeated SRs it is difficult to reach the maintenance dose of venom, usually corresponding to $100 \mathrm{mcg}$ [1]. Mild to moderate SRs may be averted by pre-treatment with antihistamines [3], while for severe SRs pre-treatment with omalizumab is indicated, as shown by some studies reporting its preventative capacity [4-6]. However, a negative study was published [7]. We describe the case of a patient with repeated SRs to

\footnotetext{
*Correspondence: elisa.boni@asst-lariana.it

${ }^{1}$ Allergy Unit, Sant'Anna Hospital, ASST Lariana, Via Napoleona 60, 22100 Como, Italy

Full list of author information is available at the end of the article
}

honeybee VIT who initially was apparently not responsive to the omalizumab treatment but achieved the complete prevention of SRs by dose increase.

\section{Case presentation}

The patient is a woman exposed to honeybee stings because her father is a beekeeper. At the age of 22 years she experienced a SR of grade 4 severity according to Mueller [8] after a single bee sting. Honeybee venom hypersensitivity was then diagnosed by skin tests and VIT for bee venom was started. However, the treatment was withdrawn early, due to repeated SRs to VIT. No other stings until the age of 47 years when the patient had a further SR (again grade 4 according to Mueller) after a bee sting. Patient's clinical features are reported in Table 1. According to clinical history, no additional allergy neither other medical conditions were present. In 2013, VIT for bee venom was then scheduled by honeybee venom from Stallergenes (Antony, France) but already during the build-up phase, at the dose of 
Table 1 Patient's clinical features at first visit

\begin{tabular}{|c|c|}
\hline Age at first visit in our clinic & 47 years old \\
\hline Sex & Female \\
\hline Concomitant allergies & None \\
\hline Concomitant diseases & None \\
\hline Previous systemic reactions of grade IV Muller & Yes \\
\hline $\begin{array}{l}\text { Number of previous attempts of VIT with HB venom withdrawn for repeated systemic reactions } \\
\text { during build-up phase }\end{array}$ & 3 \\
\hline Skin test & $\begin{array}{l}\text { Prick test HB venom: } 20 \mathrm{~mm} \\
\text { (hystamine: } 10 \mathrm{~mm} \text { ) }\end{array}$ \\
\hline Total lgE & $51 \mathrm{kU} / \mathrm{l}$ \\
\hline s-lgE HB & $20.3 \mathrm{U} / \mathrm{ml}$ \\
\hline s-lgE Api m 1 & $7.93 \mathrm{U} / \mathrm{ml}$ \\
\hline s-lgE Api m 10* & $0.00 \mathrm{U} / \mathrm{ml}$ \\
\hline s-lgE CCD & $0.00 \mathrm{U} / \mathrm{ml}$ \\
\hline Basal tryptase & $2.4 \mathrm{ng} / \mathrm{ml}$ \\
\hline Mastocytosis in bone marrow (biopsy performed) ${ }^{* *}$ & Absent \\
\hline KIT mutation ${ }^{* *}$ & Absent \\
\hline
\end{tabular}

* performed in 2015; ** performed in 2016

$10 \mathrm{mcg}$ of venom, a SR with angioedema of the glottis, cough, itching of hands and feet occurred, requiring epinephrine administration for resolution of the symptoms (Table 2). Premedication with terfenadine $180 \mathrm{mg}$ twice a day in the three days before VIT was attempted but anaphylaxis occurred again at the dose of $10 \mathrm{mcg}$ and administration of epinephrine was again necessary. Therefore, VIT for bee was once more planned using premedication with terfenadine and anti-IgE for preventing SRs. Omalizumab $300 \mathrm{mg}$ was administered twice with a 14 day interval during the build-up phase of VIT with a modified rush schedule at weekly interval (Table 3 ). However, when reaching the dose of 10 mcg the patient had cough and dysphagia. Changing the premedication to omalizumab plus intravenous hydrocortisone $500 \mathrm{mg}$, intravenous ranitidine $50 \mathrm{mg}$ and cetirizine $10 \mathrm{mg} / \mathrm{os}$, a maintenance dose of $200 \mathrm{mcg}$ of bee venom was reached in 11 weeks and well tolerated in the following months. This suggested to step down omalizumab to $150 \mathrm{mg}$ every 2 weeks and using oral premedication with prednisone $25 \mathrm{mg}$, rupatadine $10 \mathrm{mg}$ and ranitidine $150 \mathrm{mg}$. VIT and omalizumab administrations were set on different days. However, when omalizumab was reduced to $150 \mathrm{mg}$ once a month a SR requiring epinephrine occurred. Therefore, the dose of omalizumab was doubled to $300 \mathrm{mg}$ once a month along with the oral premedication with the usual drugs letting the patient tolerating the monthly dose of $200 \mathrm{mcg}$ of bee venom. However, seven months later, the same premedication regimen was not able to prevent a new SR to VIT. Finally, when increasing the dose of omalizumab to $450 \mathrm{mg}$ monthly, 2 days before VIT, preceded by oral premedication with prednisone, rupatadine and
Table 2 Previous attempts of buildup phase with HB venom

\begin{tabular}{llll}
\hline Week no. & $\begin{array}{l}\text { Premedica- } \\
\text { tion }\end{array}$ & $\begin{array}{l}\text { HB venom cumula- } \\
\text { tive dose }(\mathbf{m c g})\end{array}$ & Adverse Reactions \\
\hline 1 & & 4.11 & None \\
2 & & 10 & $\begin{array}{l}\text { Ocular itching } \\
3\end{array}$ \\
5 & 5 & Anaphylaxis \\
6 & Terfenadine & 4.11 & None \\
7 & Terfenadine & 10 & None \\
\hline
\end{tabular}

ranitidine 12 and $2 \mathrm{~h}$ before VIT, the patient no longer suffered from SRs over the last 14 months and is still under regular treatment.

\section{Conclusions}

VIT is a highly effective treatment but not all patients are protected from SRs by the usual maintenance dose of $100 \mathrm{mcg}$. Rueff et al. demonstrated that in all patients not completely protected from stings a protective dose may be individuated, that in rare cases may be as high as 400 mcg [9].

The case we report shows that also the search of the dose of omalizumab able to protect a patient with repeated SRs to VIT may be demanding, but this pursuit is warranted by the need to provide to this kind of patient, by an adequate VIT, the protection from potentially life-threatening reactions. In previous reports, the minimal effective dose of omalizumab to protect from systemic reactions to VIT was $150 \mathrm{mg}$ [10], thus the 
Table 3 Build up phase with administration of omalizumab

\begin{tabular}{|c|c|c|c|c|}
\hline Week no. & Premedication & Omalizumab (mg) & HB venom cumulative dose $(\mathrm{mcg})$ & Adverse reactions \\
\hline 1 & & 150 & & \\
\hline 3 & & 300 & & \\
\hline 4 & Terfenadine & & 4.11 & None \\
\hline 5 & Terfenadine & 300 & 10 & Cough and dysphagia \\
\hline 6 & $\begin{array}{l}\text { Hydrocortisone } \\
\text { Ranitidine } \\
\text { Cetirizine }\end{array}$ & & 20 & None \\
\hline 7 & $\begin{array}{l}\text { Hydrocortisone } \\
\text { Ranitidine } \\
\text { Cetirizine }\end{array}$ & 300 & 30 & Ocular and palmar itching \\
\hline 8 & & 300 & & \\
\hline 9 & $\begin{array}{l}\text { Hydrocortisone } \\
\text { Ranitidine } \\
\text { Cetirizine }\end{array}$ & & 45 & None \\
\hline 10 & $\begin{array}{l}\text { Hydrocortisone } \\
\text { Ranitidine } \\
\text { Cetirizine }\end{array}$ & 300 & 60 & None \\
\hline 11 & $\begin{array}{l}\text { Hydrocortisone } \\
\text { Ranitidine } \\
\text { Cetirizine }\end{array}$ & & 80 & None \\
\hline 12 & & 300 & & \\
\hline 13 & $\begin{array}{l}\text { Hydrocortisone } \\
\text { Ranitidine } \\
\text { Cetirizine }\end{array}$ & & 100 & None \\
\hline 14 & $\begin{array}{l}\text { Hydrocortisone } \\
\text { Ranitidine } \\
\text { Cetirizine }\end{array}$ & 300 & 130 & None \\
\hline 15 & $\begin{array}{l}\text { Hydrocortisone } \\
\text { Ranitidine } \\
\text { Cetirizine }\end{array}$ & & 170 & None \\
\hline 16 & $\begin{array}{l}\text { Hydrocortisone } \\
\text { Ranitidine } \\
\text { Cetirizine }\end{array}$ & 300 & 200 & None \\
\hline
\end{tabular}

search of the protective dose should start from $150 \mathrm{mg}$, with increase to $300 \mathrm{mg}$ and, possibly, to $450 \mathrm{mg}$ in case of incomplete protection. The most appropriate combination therapy including also corticosteroids and antihistamines is not yet established and needs be investigated.

\section{Abbreviations}

SR: systemic reaction; VIT: venom immunotherapy; mcg: micrograms; mg: milligrams.

\section{Authors' contributions}

All authors contributed in collection of data and in the writing of the manuscript.

\section{Author details}

1 Allergy Unit, Sant'Anna Hospital, ASST Lariana, Via Napoleona 60 22100 Como, Italy. ${ }^{2}$ Allergy/Cardiac and Pulmonary Rehabilitation ASST G. Pini/CTO, Via Bignami 1, 20126 Milan, Italy.

\section{Acknowledgements}

None.

\section{Competing interests}

E.B. has received a grant from Allergy Therapeutics for a scientific consultancy; C.I. is a scientific consultant for Stallergenes Italy; M.M. has received a grant from ALK for the project "ALK Venom Expert".

\section{Consent for publication}

Signed consent to publish was obtained from the patient.

Received: 17 June 2016 Accepted: 16 October 2016

Published online: 24 October 2016

\section{References}

1. Boyle RJ, Elremeli M, Hockenhull J, Cherry MG, Bulsara MK, Daniels M, Oude Elberink JN. Venom immunotherapy for preventing allergic reaction to insect stings. Cochrane Database Syst Rev 2012: CD008838.

2. Incorvaia C, Frati F, Dell'Albani I, Robino A, Cattaneo E, Mauro M. Safety of hymenoptera venom immunotherapy: a systematic review. Expert Opin Pharmacother. 2011;12(16):2527-32.

3. Gorska L, Chelminsha M, Kuziemski K, Skrzypski M, Niedoszytko M, Damps-Konstanska l, et al. Analysis of safety, risk factors and pretreatment methods during rush hymenoptera venom immunotherapy. Int Arch Allergy Immunol. 2008;147(3):241-5. 
4. Wieczorek D, Kapp A, Wedi B. Intolerance of specific immunotherapy with Hymenoptera venom: jumping the hurdle with omalizumab. Hautarzt. 2014;65(9):791-5.

5. Galera C, Soohun N, Zankar N, Caimmi S, Gallen C, Demoly P. Severe anaphylaxis to bee venom immunotherapy: efficacy of pre-treatment and concurrent treatment with omalizumab. J Investig Allergol Clin Immunol. 2009;19(3):225-9.

6. Kontou-Fili K. High omalizumab dose controls recurrent reactions to venom immunotherapy in indolent systemic mastocytosis. Allergy. 2008;63(3):378.

7. Soriano Gomis V, Gonzalez Delgado P, Niveiro Hernandez E. Failure of omalizumab treatment after recurrent systemic reactions to bee-venom immunotherapy. J Investig Allergol Clin Immunol. 2008;18(3):225-6.
8. Mueller HL. Diagnosis and treatment of insect sensitivity. J Asthma Res. 1966;3:331-3.

9. Rueff F, Wenderoth A, Przybilla B. Patients still reacting to a sting challenge while receiving conventional Hymenoptera venom immunotherapy are protected by increased venom doses. J Allergy Clin Immunol. 2001;108:1027-32.

10. Palgan K, Bartuzi Z, Gotz-Zbikowska M. Treatment with a combination of omalizumab and specific immunotherapy for severe anaphylaxis after a wasp sting. Int J Immunopathol Pharmacol. 2014;27:109-12.

\section{Submit your next manuscript to BioMed Central and we will help you at every step:}

- We accept pre-submission inquiries

- Our selector tool helps you to find the most relevant journal

- We provide round the clock customer support

- Convenient online submission

- Thorough peer review

- Inclusion in PubMed and all major indexing services

- Maximum visibility for your research

Submit your manuscript at www.biomedcentral.com/submit 